\title{
Davranışsal Finans Bağlamında Kendine Aşırı Güven, Kontrol Yanılsaması ve İyimserlik Önyargılarının Ölçülmesi: Üniversite Öğrencileri Örneği*
}

\section{Measurement of Overconfidence, Illusion of Control and Optimism in the Context of Behavioral Finance: Case of University Students}

Bilgehan Tekin ${ }^{\text {a,** }}$

${ }^{a}$ Dr. Öğr. Üyesi, Çankırı Karatekin Üniversitesi, İktisadi ve İdari Bilimler Fakültesi, İşletme Bölümü, 18100, Çankırı/Türkiye. ORCID: 0000-0002-4926-3317

\section{MAKALE BİLGİSI}

\section{Makale Geçmişi:}

Başvuru tarihi: 03 Eylül 2019

Düzeltme tarihi: 10 Nisan 2020

Kabul tarihi: 28 Nisan 2020

\section{Anahtar Kelimeler:}

Davranışsal Önyargılar,

Kendine Aşırı Güven,

Kontrol Yanılsaması,

İyimserlik,

Ölçme

\section{ARTICLE INFO}

\section{Article history:}

Received 03 September 2019

Received in revised form 10 April 2020

Accepted 28 April 2020

\section{Keywords:}

Behavioral biases,

Overconfidence,

The İllusion of Control,

Optimism,

Measurement
ÖZ

Davranışsal finans, piyasa anomalilerinin yanı sıra bu anımalilere neden olan önyargıların incelenmesini de konu almaktadır. Literatüre bakıldığında kişilerin karar süreçleri üzerinde etkisi olduğu belirtilen çok sayıda önyargıdan bahsedildiği görülmektedir. Bunlar arasında üzerinde ayrıca durulan önyargıların ise kendine aşırı güven, kontrol yanılsaması ve aşırı iyimserlik olduğu dikkati çekmektedir. Bu çalışmada bu üç önyargının ölçülmesini hedefleyen ifadelerden oluşan ölçeklerin Türkiye'de üniversite öğrencileri üzerindeki güvenilirliği ve geçerliliği test edilmiştir. Önyargıları ölçülmesini hedefleyen ve bu çalıșmada kullanılan ölçeğin ilk halinde 19 madde yer almaktadır. Öğrencilerin demografik bilgilerini de içeren anket formu farklı üniversitelerde öğrenim gören toplam 522 öğrenciye uygulanmıştır. Yapılan analizler sonucunda ölçeğin son halinin Cronbach Alfa değerinin 0,825 olduğu ve ölçekte yer alan ifadelerin 4 faktör altında toplandığ 1 tespit edilmiştir.

\section{Giriş}

Geleneksel ve modern finans teorileri, kişilerin faydalarını maksimize etme amacı güden rasyonel bireyler olmaları nedeniyle duygudan ve diğer psikolojik etkenlerden yoksun olarak rasyonel kararlar alacakları varsayımı altında gelişim göstermiştir. Modern kapitalizmin babası olarak anılan Adam Smith (1776) bireylerin tam ve mükemmel bilgi

\begin{abstract}
A B S T R A C T
Behavioral finance is concerned with analyzing market anomalies as well as biases that cause these anomalies. There are many biases that are stated to have an effect on the decision processes of individuals in behavioural finance literature. It is noteworthy that the biases emphasized among them are overconfidence, illusion of control and extreme optimism. This study aimed at measuring the scale that consists of statements about these three biases on college students in Turkey and reliability and validity of this scale was tested. There are 19 items in the first version of the scale that aims to measure biases and used in this study. The questionnaire, including the demographic information of the students, was applied to a total of 522 students studying at different universities. As a result of the analyzes, it was determined that the final version of the scale Cronbach's Alpha value is 0.825 and the items in the scale were collected under 4 factors.
\end{abstract}

\footnotetext{
* Bu çalışma 26-29 Ekim 2018 tarihinde Niğde'de düzenlenen "International Congress on Politic, Economic and Social Studies (ICPESS)" başlıklı kongrede sunulmuş bildirinin geliştirilmiş ve yeniden düzenlenmiş halidir.

** Sorumlu yazar/Corresponding author.

e-posta: btekin@karatekin.edu.tr
} 
Bunlar, beklenen fayda teorisi, beklenti teorisi ve ortalama varyans analizidir (Hens ve Bachmann, 2008:12). 1738 yılında Daniel Bernoulli tarafından ilk çalışmaları yapılan ve daha sonra Von Neumann ve Morgenstern tarafindan 1944 yılında "beklenen fayda teorisi" adı altında daha formal bir hale dönüştürülen model, finans modellerinin temel dayanak noktalarından biridir (Von Neumann ve Morgenstein, 1953, 2007). Beklenen fayda teorisinde, bireylerin karar verme süreçlerinde olasılıksal hesaplamaları dayanak aldıkları ve en fazla faydayı sağlayacak bir biçimde karar verdikleri varsayılmaktadır (Tekin, 2016:79).

Daniel Kahneman ve Amos Tversky 1979 yılında beklenen fayda modeline alternatif bir yaklaşım getiren "Beklenti Teorisi: Risk Altında Verilen Kararların Analizi” başlıklı çalışmayı gerçekleştirmişlerdirr. Bu çalışmada beklenen fayda teorisinin varsayımları eleştirilerek bireylerin karar verme süreçlerinden sapma nedenleri üzerinde durulmuş ve beklenen fayda teorisine karşı "Beklenti Teorisi" ortaya konulmuştur. Beklenti teorisi çalışmasının bulgularından biri, bireylerin kayıptan kaçınmak için risk almalarına karşın, kazanç söz konusu olduğunda riskten kaçındıklarını şeklindedir. Kahneman ve Tversky (1979), bireylerin belirli bir referans noktasına göre hareket ettiklerini ve kayıplara, aynı miktardaki kazançlardan daha fazla değer atfettiklerini öne sürmüşlerdir (Tekin, 2016:80).

$\mathrm{Bu}$ süreç ve sonrasında psikoloji, davranış bilimleri ve davranışsal finans alanlarında yapılan çalışmalar, bireylerin çoğunlukla rasyonaliteden uzak kararlar alarak temel finans modellerinin ve hipotezlerinin varsayımlarından sapmalar sergilediklerini göstermiştir. Literatürde, bireylerin, yargıya varma veya karar verme aşamalarında rasyonel davranıştan sapmalarına neden olan iki olgudan söz edilmektedir. Bunlar, davranışsal önyargılar (behavioral biases) ve hevristiklerdir (heuristics). 1970'li y1llardan itibaren, Kahneman ve Tversky tarafından yapılan çalışmalar serisinin etkisiyle, beklenen fayda teorisi ve rasyonel karar olguları daha fazla sorgulanmaya ve yumuşatılmaya başlanmıştır. Bu bağlamda, önyargı ve hevristikler üzerine yapılan çalışmaların sayısı da önemli derecede artmıştır. $\mathrm{Bu}$ çalışmaların bir sonucu olarak davranıșsal finans disiplini ortaya çıkmıştır. Davranışsal finans çalışmalarının odak noktası bireylerin finansal karar verme süreçlerinde sergiledikleri davranışsal önyargı ve hevristikler ile piyasalarda görülen ve etkin piyasalar hipotezinden sapmaları ifade eden anomalilerin incelenmesinden oluşmaktadır.

Bireyler çoğu zaman bilişsel hatalar nedeniyle hatalı karar verme davranışı sergiler. Söz konusu bilişsel hatalar davranışsal önyargılardır. $\mathrm{Bu}$ önyargılar, bilişsel ve duygusal anlamda ifade edilebilir. Davranışsal finans alanında yapılan çalışmalara sıklıkla konu olan belli başlı bilişsel önyargılar arasında, kendine aşırı güven, kayıptan kaçınma, dayanak noktası, iyimserlik, kendine atfetme, mental muhasebe, muhafazakarlık, çerçeveleme, aşina olma, statüko, temsiledilebilirlik sayılabilir. Diğer yandan duygusal önyargılar, korku, üzüntü, heyecan vb. psikolojik faktörleri ifade eder ve bireylerin karar verme süreçlerinde çarpıklık ya da bozukluk ortaya çıkarmaktadırlar. Shefrin (2000), bilişsel faktörlerin insanların sahip oldukları bilgilerin organize edilmesini sağladığını, duygusal faktörlerin ise insanların bilgi sahibi olduklarını hissetmelerini sağladığını ifade etmektedir.
Baker, Ruback ve Wurgler (2004), davranışsal finans literatürünün iki temel bloktan meydana geldiğini belirtmektedirler. Bunlardan birincisi yatırımcıların kararlarını etkileyen davranışsal önyargılar ya da yatırımcı davranışlarının verilen kararlara etkisidir. İkincisi ise yönetici davranışlarını etkileyen davranıșsal önyargılar ya da yönetici davranışsal önyargılarının firmalarda verilen kararlara etkisidir. Psikoloji ve davranış bilimleri literatürlerinden anlaşıldığı üzere, bireylerin karar verme ve yargılama süreçlerinde etkisi olduğu belirtilen oldukça fazla sayıda önyargı, hevristik, duygu, sezgi vb. psikolojik ve davranışsal faktör olduğu görülmektedir. $\mathrm{Bu}$ faktörlerin etkili bir şekilde ölçülebilmesi yapılacak analizlerin başarıya ulaşmasında ön koşuldur.

$\mathrm{Bu}$ çalışmada, literatürde yer alan ve davranışsal önyargıların ölçülmesini ve bu önyargıların yatırım kararları üzerindeki etkisini konu alan çalışmalardan hareketle davranışsal finans alanında üzerinde oldukça sık durulan üç temel davranışsal önyargının ölçülmesi amaçlanmıştır. Burada amaç, ilgili ölçeklerin ve ifadelerin konu ile ilgili sonraki süreçte yapılacak çalışmalar için geçerli ve güvenilir bir yapıya sahip olup olmadıklarının incelenmesi ve bu bağlamda gelecek çalışmalarda kullanılabilecek nispeten tutarlı bir ölçek ortaya koymaktır. Davranışsal önyargıların yatırım kararlarına etkisinin ölçüldüğü birçok çalışma olmakla birlikte, bu çalışmalarda kullanılan ölçeklerin birçoğu geçerlilikk ve güvenilirlik analizlerine dayanmamaktadır. Bu çalışma ile amaçlanan bir diğer olgu literatürün bu eksiğini kapatmaya ve bu yöndeki çabalara katkıda bulunmaktır. $\mathrm{Bu}$ bağlamda yapılan çalışmada, bireysel ve kurumsal karar almalarda etkisi olduğu daha önce yapılan çalışmalarda ortaya konan üç davranışsal önyargının tek bir anket formu ile ölçülebilmesi amaçlanmıştır. Sonraki çalışmalarda, bu çalışmada ortaya konulan anket formuna bireylerin çeşitli finansal kararlarını da içeren ifadelerin eklenerek, çok değişkenli istatistiksel analizleri yapabilme imkanı, etkinlik, kolaylık ve zamandan tasarruf sağlanacağı düşünülmektedir.

Davranışsal önyargıların yatırım kararlarına etkisini konu alan ve daha önce yapılmış çalıșmalarda genel olarak ele alınan davranışsal önyargıların ise kendine aşırı güven, kontrol yanılsaması ve iyimserlik veya aşırı iyimserlik olduğu görülmüştür. Çalışmanın bundan sonraki başlıkları altında öncelikle söz konusu üç davranışsal önyargı ile ilgili bilgilere yer verilecek olup daha sonra yapılan analizlere geçilecektir.

\section{Literatür Taraması}

\subsection{Kendine Așırı Güven Davranıșsal Önyargısı}

Kendine aşırı güven kavramsal olarak ilk defa Oskamp (1965) tarafindan açıklanmıştır. Kendine aşırı güven, kişilerin karar veya yargıya varma süreçlerine etki eden bir yanılsama, davranışsal bozulma veya eğilim olarak tanımlanır. Odean (1998), kendine aşırı güvenin psikoloji literatüründe, kişilerin kendi yetenek ve bilgilerine olan gereğinden fazla güvenlerini ifade ettiğini bildirmiştir. Conger ve Wolstein (2004) ise, kendine aşırı güvenin, kişilerin yeteneklerini, geleceğe yönelik olumlu beklentilerini, olayların sonuçlarını ya da sahip oldukları bilgilerin doğruluğunu abartmasını ifade ettiğini 
bildirmektedirler. Kendine aşırı güven, bir başka deyişle, kişilerin sahip oldukları bilgilerinin sınırlarını bilmemeleri sonucu ortaya çıkmaktadır (Tekin, 2019:294).

Svenson (1981), tarafından yapılan çalışmada kendine aşırı güven kaynağı olarak, kişilerin kendilerini yetenekli gördükleri konularda ve koşullarda ortalama bir bireyden daha iyi olduklarına inanmaları olduğunu belirtmektedir. Bireylerin bu tutumuna davranışa ortalamadan daha iyi etkisi (better than average effect) adı verilmiştir. Taylor ve Brown (1988), bireylerin kendileri söz konusu olduğunda gerçekçi olmayan pozitif beklentilere veya inançlara sahip olduklarını belirtmiştir.

Davranışsal finans literatüründe, kendine aşırı güven önyargısına ilişkin çok sayıda çalışma yer almaktadır. Kendine aşırı güven önyargısı, finansal piyasaları ve yatırımcı davranışları temelinde ele alındığında, yatırımcıların yetenek, bilgi ve tecrübelerine gerçekçi olmayan güvenlerini ifade eder (Michailova, 2010:2). Davranışsal finans, kendine aşırı güvenin, yatırımcıların finansal piyasalardaki yatırım kararlarını etkileyen ana unsur olduğunu belirtmektedir. Bu önyargının kaynağı, yetenek, bilgi, tecrübe unsurlarına gereğinden fazla güvenilmesi ve mevcut ve olası risklerin gözard edilmesidir.

Finansal piyasalarda işlem yapan kendine aşırı güvenli yatırımcılar, genel olarak riskli pozisyon alırlar ve diğer yatırımcılara göre işlem hacimleri daha yüksektir (De Bondt ve Thaler, 1985; Shiller, 2000; Caballe ve Sakovics, 2003, Glaser ve Weber, 2007; Trinugroho ve Sembel, 2011; Scheinkman ve Xiong, 2003; Benos, 1998; Daniel ve diğerleri, 1998).

Literatürde yer alan çalışmalardan (Alrabadi, ALGharaibeh ve Zurigat, 2011; Arif ve Khan, 2013; Chitra ve Jayashree, 2014; Riaz ve Iqbal, 2015) ve çeşitli bilimsel toplantılarda biraraya gelinen psikoloji ve davranışsal finans alanlarında çalışan akademisyenlerin görüşlerinden hareketle başta 10 madde olarak belirlenen kendine aşırı güven davranışsal önyargısını tespit etmeye yönelik ifadeler Tablo 1'de görüldüğü gibi 6 maddeye düşürülmüştür. İfadelere katılım derecesi 5'li Likert tipi ölçek ile ölçülmüştür (1: Kesinlikle Katılmıyorum,...,5: Tamamen Katılıorum).

Tablo 1. Kendine Aşırı Güven Önyargısı İfadeleri

A1. Yatırım yapma ve yönetme konusunda kendi yeteneklerime güvenirim.

A2. Kendi yeteneklerime güvendiğim için fazla risk alırım.

A3. Bir karar alırken kendi görüşlerim dışındaki görüşleri fazla dikkate almam.

A4. Çevreme yatırım tavsiyelerinde bulunurum ve bundan asla çekinmem.

A5. Verdiğim kararın doğruluğundan asla şüphe duymam.

A6. Önceki kararlarımın isabet derecesi gelecekte alacağım kararlar için bana güven verir.

\subsection{Kontrol Yanılsaması Davranışsal Önyargısı}

Kontrol yanılsaması (illusion of control) olarak adlandırılan kavram bireylerin olayların çıktıları üzerinde gerçekçi olmayan kontrol etme algılarını ifade etmektedir. Yani bireylerin, gerçeklerle bağdaşmayacak bir şekilde olayların sonuçlarını etkileyebilecekleri algısına sahip olmaları durumudur. Montier (2007) kontrol yanılsamasını, bireylerin kontrol edilemez durumların sonuçlarını kontrol edebileceklerine olan rasyonel olmayan inançları olarak ifade etmektedir. Pompian'a (2012) göre kontrol yanılsaması aslında, insanların olayların sonuçlarını kontrol edebildiklerini veya etkileyebileceklerini düşünmelerine neden olan bir yanılsamadır. Yazarın yaptığı çalışma, seçeneklerin, görev aşinalıklarının, rekabetin ve aktif katılımın insanların kendilerine olan güvenlerini artırıp bu tür illüzyonlar üretebileceğini göstermiştir.

Kontrol yanılsamasını ilk olarak ortaya atan kişi ise Langer (1975)' dır. Langer yayınladığı "The illusion of control" başlıklı çalışmasında bir deney grubu ve şans oyunu üzerinden kontrol yanılsamasının varlığını ve derecesini ortaya koymaktadır. Langer söz konusu çalışmasında kontrol yanılsamasını "uygunsuz bir başarı beklentisinin objektif ve garanti bir beklentiden yüksek olması durumudur" şeklinde tanımlamaktadır. Çalışmasında tercih, görev aşinalığı, rekabet ve aktif katılım gibi faktörlerin tümünün abartılı güven inançlarına neden olduklarını belirtmektedir (Charness ve Gneezy, 2003:134). Kontrol yanılsaması aynı zamanda, öngörülen risklerin yeteri kadar doğru değerlendirilememesine neden olan bir unsurdur (Schwenk, 1984). Schwenk bir yöneticinin olumlu kontrol kavramı yanılgılarının bir görevin başarı oranını abartmasına yol açacağını ifade etmektedir.

Literatürde yer alan çalışmalardan (Langer, 1975; Nosic ve Weber, 2010; Pompian, 2012; Metilda, 2015) ve uzman görüşlerinden hareketle başta 7 madde olarak belirlenen kontrol yanılsaması ile ilgili sorular aşağıdaki Tablo 2'de görüldüğü gibi 6 maddeye düşürülmüştür. İfadelere katılım derecesi 5'li Likert tipi ölçek ile ölçülmüştür (1: Kesinlikle Katılmiyorum,..,5: Tamamen Katıliyorum).

Tablo 2. Kontrol Yanılsaması Önyargısı İfadeler

B1. Her zaman verdiğim kararların oldukça isabetli olduğunu düşünürüm.

B2. Verdiğim kararların sonuçlarını tam olarak kestirebilirim.

B3. Yaptı̆̆ım bir yatırımın getirisini tam olarak tahmin edebilirim.

B4. Bir karar verilmesi gereken durumda benim vereceğim karar her zaman en doğru karardır.

B5. Genel olarak, verdiğim kararların doğruluğu konusunda kendimden eminimdir.

B6. Kendimi bilgi birikimim açısından benimle aynı statüde olan diğer insanların üzerinde görüyorum.

\section{3. İyimserlik Davranışsal Önyargısı}

Literatüre bakıldığında iyimserlik (optimism) önyargısının kendine aşırı güven ile birlikte anıldığı ve onun bir bileşeni olduğunun ileri sürüldüğü görülmektedir. Malmendier ve Tate (2007), kendine aşırı güven önyargısını yeteneklerin ve olayların olumlu sonuçlarının abartması ve genel anlamda geleceğe yönelik beklentilerde aşırı iyimserlik gösterilmesi şeklinde tanımlamışlardır. Weinstein (1980) iyimserliği, aşırı güvenden ayrı bir önyargı çeşidi olarak ele almaktadır. Weinstein (1980), iyimserliği, gelecekle ilgili beklentilerin gerçeklerden uzak olması şeklinde ifade etmektedir (Weinstein, 1980:806-808). 
Weinstein tarafindan 1980 yılında yapılan, "Unrealistic optimism about future life events" başlıklı çalışma iyimserliğin akademik disiplin içerisinde incelendiği ilk çalışmalardan sayılır. İyimserlik kısaca, gelecekle ilgili beklentilerin veya elde edilecek kazançların abartılı tahmin edilmesi eğilimi şeklinde tanımlanmaktadır (Weinstein, 1980; Hilton, 2001). Shefrin (2007) ise aşırı iyimserliği arzu edilen olumlu sonuçların sıklığının aşırı tahmini ve daha az olumlu sonuçların hafife alınması şeklinde tanımlamıştır.

Yatırımcı boyutunda ise aşırı iyimserliğin kişilerin ortalama getirilerinin abartılı tahmin edilmesini ifade ettiği belirtilmektedir (Barone-Adesi, Mancini ve Shefrin, 2013). İyimserlik önyargısının aynı zamanda, kişilerin kendi yeteneklerini abartmaları sonucu gerçekçi olmayan iyimser bir gelecekteki performans algısına neden olduğu belirtilmektedir (Kahneman ve Riepe, 1998). Brown ve Cliff (2005) tarafından yapılan çalışmada yatırımcıların duygularının bir menkul kıymeti değerlendirme yeteneklerini etkilediği ve yatırımcıların aşırı iyimserlik yanlılığından etkilendikleri belirtilmiştir.

Literatürde yer alan çalışmalardan (Scheier, Carver ve Bridges, 1994) ve uzman görüşlerinden hareketle başta 10 madde olarak belirlenen iyimserlik ile ilgili sorular aşağıdaki Tablo 3'te görüldüğü gibi 7 maddeye düşürülmüştür. İfadelere katılım derecesi 5'li Likert tipi ölçek ile ölçülmüştür (1: Kesinlikle Katılmıyorum,...,5: Tamamen Katıliyorum).

Tablo 3. İyimserlik Önyargısı İfadeleri

C1. Sonucu belirsiz bir durumla karşılaştığımda genelde en iyisinin olmasını beklerim.

C2. Rahatlamak için çok çaba sarf etmem.

C3. Geleceğimle ilgili olarak her zaman iyimserimdir.

C4. Arkadaşlarımla vakit geçirerek çok eğlenirim.

C5. Sürekli olarak bir şeylerle meşgul olmak benim için önemlidir.

C6. Çok kolay üzülen biri değilimdir.

C7. Genel olarak başıma iyi şeylerin geleceği yönündeki beklentim kötü şeylerin geleceği beklentisinden daha fazladır.

\section{Yöntem ve Bulgular}

$\mathrm{Bu}$ çalışmanın örneklemini (çalışma gurubunu) kolayda örnekleme ile seçilen ve Çankırı Karatekin Üniversitesi ile Karabük Üniversitesi'nde öğrenim gören toplam 522 öğrenci oluşturmuştur. Veriler, 2016-2017 yıllarında Güz ve Bahar dönemlerinde toplanmıştır. Öğrenciler, İşletme, İktisat, Siyaset Bilimi/Kamu Yönetimi ve Uluslararası İlișkiler olmak üzere İktisadi ve İdari Bilimler Fakültelerinde 4 temel bölümde eğitim gören öğrenciler arasından seçilmiştir. Örneklemin öğrencilerden seçilmiş olması gelecekte yatırım yapabilecek refah düzeyine ulașacakları beklentisinden ileri gelmektedir. Bununla birlikte öğrencilerin gelecekte yatırım yapma niyetinde olmalarına ve yatırım araçları ile ilgili belli düzeyde bilgi sahibi olmalarına özen gösterilmiştir.

Toplam 19 maddeden oluşan ölçek (Ek 1) öncelikle 2 hafta ara ile toplam 81 öğrenciye iki kere uygulanarak verilen cevapların kararlılığı ölçülmüştür. İki uygulama sonrası verilen cevaplar arasındaki korelasyon katsayısı (r) 0,91 olarak ölçülmüştür (Uygulamalar arası verilen cevaplar yüksek düzeyde pozitif ilişkilidir). Daha sonra, anket formunun bireylerin davranışsal önyargı düzeylerini ölçüp ölçmediğini belirlemek amacıyla farklı üniversitelerde öğrenim gören 2., 3. ve 4. sinıf ile uzatma durumunda bulunan toplamda 522 öğrenciye uygulanmıştır. Toplanan anketlerden 502'si analize uygun bulunmuştur.

Toplanan veriler üzerinden frekans, madde (madde ve ölçek korelasyon analizi) ve yapı geçerliliği analizleri (faktör analizi) ile güvenilirlik analizleri yapılmıștır. Toplanan verilere ait betimsel istatistikler Tablo 4'te görüldüğ̈̈ gibidir:

Tablo 4. Araștırmaya katılan katılımcıların tanımlayıcı istatistikleri

\begin{tabular}{cccc}
\hline & & f & \% \\
\hline \multirow{3}{*}{ Cinsiyet } & Kadın & 296 & 59,0 \\
& Erkek & 206 & 41,0 \\
& Toplam & 502 & 100,0 \\
\hline \multirow{4}{*}{ Bölümm } & & f & \% \\
& İsletme & 112 & 22,4 \\
& İktisat & 237 & 47,1 \\
& Siyaset & 92 & 18,4 \\
& Uluslararası & 61 & 12,1 \\
& Toplam & 502 & 100,0 \\
\hline \multirow{4}{*}{ Yaş } & & $\mathbf{f}$ & \% \\
& $18-20$ & 218 & 43,4 \\
& $21-25$ & 277 & 55,1 \\
& $26-30$ & 7 & 1,5 \\
& Toplam & 502 & 100,0 \\
\hline \multirow{5}{*}{ Sinıf } & & f & \% \\
& 2. Sinıf & 114 & 22,8 \\
& U. Sinıf & 275 & 54,8 \\
& U. Sinıf & 96 & 19,1 \\
& Toplam & 17 & 3,3 \\
& Durumunda & 502 & 100,0 \\
\hline
\end{tabular}

\subsection{Madde ve Yapı Geçerliliği Analizleri}

Literatüre bakıldığında, Likert tipi ölçeklerin geçerliklerinin incelenmesi amaciyla genel olarak faktör analizinden yararlanıldığı görülmektedir. Faktör analizi, aynı olguyu ölçen değişkenleri bir arada toplamaya ve değişken sayısını azaltarak aynı olguyu daha az değişkenle ölçmeye imkan tanımaktır. Ayrıca, ölçeklerin yapı geçerliklerinin ortaya konulmasında madde geçerliği analizinden de yararlanılmaktadır. Madde geçerliği analizinin amacı, ölçülmek istenen olguyu diğerleriyle karıştırmadan ölçebilecek maddeleri seçmektir. $\mathrm{Bu}$ sayede kendi içerisinde tutarlı bir ölçek geliștirilmiş olunur. Ölçeklerde yer alan soruların ölçülmek istenen olguyu ölçme derecelerinin tespit edilebilmesi için kullanılan yöntemlerden biri korelasyona dayalı madde analizidir. Çalışmanın bu bölümünde öncelikle korelasyona dayalı madde analizi sonuçları verilip yorumlanacaktır. Daha sonra faktör analizi sonuçlarına değinilecektir.

Tablo 5, üç davranışsal önyargıya ait ölçeğin ve anketin bütününün ilgili ölçekteki her bir madde ile ilişkisini göstermektedir. Buna göre üç davranışsal önyargı ölçeği ayrı ayrı ve bütün olarak ele alındığında ölçeklerdeki maddelerin ölçeğin bütünüyle genel olarak orta ve yüksek düzeylerde pozitif ilişkili oldukları görülmektedir. Dolayısıyla ölçeklerde yer alan tek tek her bir madde puanları, davranışsal önyargı ölçeği puanları ve genel ölçek 
puanları ile orta ve yüksek düzeyde ilişkilidir. Bu nedenle her bir maddenin ölçme gücü yeterli ve anlamlıdır $(\mathrm{p}<0,05)$.

Tablo 5. Ölçek Puanı ile Madde Puanları Arasındaki Korelasyonlar

\begin{tabular}{|c|c|c|}
\hline Maddeler & Aşırı Güven Puanı (r) & $\begin{array}{c}\text { Genel Ölçek Puanı } \\
\text { (r) }\end{array}$ \\
\hline $\mathbf{A 1} \mathbf{1}^{\mathbf{a}}$ &, $728^{*}$ &, $564^{*}$ \\
\hline $\mathbf{A 2}$ &, $706^{*}$ &, $588^{*}$ \\
\hline A3 &, $454^{*}$ & $241^{*}$ \\
\hline A4 & $689^{*}$ & $463^{*}$ \\
\hline A5 &, $623^{*}$ & $416^{*}$ \\
\hline A6 &, $668^{*}$ &, $581^{*}$ \\
\hline Maddeler & $\begin{array}{c}\text { Kontrol Yanılsaması } \\
\text { Puanı } \\
\end{array}$ & Genel Ölçek Puanı \\
\hline $\mathbf{B 1}^{\mathbf{b}}$ &, $734^{*}$ &, $674^{*}$ \\
\hline B2 &, $725^{*}$ &, $634^{*}$ \\
\hline B3 & $694^{*}$ &, $538^{*}$ \\
\hline B4 &, $606^{*}$ &, $370^{*}$ \\
\hline B5 &, $731^{*}$ &, $612^{*}$ \\
\hline B6 &, $660^{*}$ &, $490^{*}$ \\
\hline Maddeler & Aşırı İyimserlik Puanı & Genel Ölçek Puanı \\
\hline $\mathrm{C1}^{\mathrm{c}}$ &, $661^{*}$ &, $526^{*}$ \\
\hline $\mathrm{C} 2$ & $460^{*}$ &, $295^{*}$ \\
\hline $\mathbf{C 3}$ &, $735^{*}$ &, $598^{*}$ \\
\hline C4 &, $706^{*}$ &, $582^{*}$ \\
\hline C5 &, $683^{*}$ &, $541^{*}$ \\
\hline C6 &, $625^{*}$ &, $496^{*}$ \\
\hline C7 &, $764^{*}$ &, $638^{*}$ \\
\hline
\end{tabular}

Yapı geçerliliği için ikinci aşamada faktör analizi yapılmıştır. Faktör analizi teknikleri doğrulayıcı ve açımlayıcı faktör analizi olmak üzere temelde ikiye ayrılır. $\mathrm{Bu}$ çalışmada açımlayıcı faktör analizi yöntemi kullanılmıştır. $\mathrm{Bu}$ yöntemin kullanılmasının nedeni bu çalışmada yer verilen ölçek ifadelerinin daha önce yapılmış çalışmalarda da kullanılmış olmasıdır.

Faktör analizine geçmeden önce, verilerin analize uygun olup olmadığının tespit edilebilmesi amacıyla KaiserMeyer-Olkin (KMO) testinin yapılması gereklidir. Test sonucunda hesaplanan KMO değerinin 0,50' nin üzerinde olması örneklemin faktör analizi için yeterli denebilecek seviyede olduğunun bir göstergesi olarak yorumlanır (Field, 2000). Bu çalışmada yapılan test sonucunda Tablo 6'da da görüldüğü gibi KMO değeri 0,874 olarak hesaplanmıştır. $\mathrm{Bu}$, faktör analizi için örneklem yeterliliğinin çok iyi seviyede olduğunun göstergesidir (Kalaycı, 2005). Ayrıca, Barlett testinin Ki-Kare değeri, $p<0,01$ anlamlılık seviyesinde 3484,761 bulunmuştur.

Faktör analizine uygunluk açısından dikkat edilen bir başka ölçüt ise kısmi korelasyon katsayılarının negatif değerlerinden oluşan ters görüntü (anti - image) korelasyon matrisinin köşegen değerleridir (Polat ve Kayaalp, 2012). $\mathrm{Bu}$ değerlerin 0,50 'den büyük olması istenir. Ters görüntü matrisinde köşegen değerlerinin 0,50 'den büyük olduğu tespit edilmiştir. Sonuç olarak faktör analizi için değişkenlerin uygun olduğuna kanaat getirilmiş ve herhangi bir değişken analizden çıkartılmamıştır.
Tablo 6. KMO ve Bartlett Testi Sonuçları

\begin{tabular}{lcr}
\hline Örneklem Yeterliliği KMO Testi &, 874 \\
\multirow{2}{*}{ Barlett Küresellik Testi } & Ki-Kare & 3484,761 \\
& Anlamlılık &, 000 \\
\hline
\end{tabular}

Daha sonra açımlayıcı faktör analizi sonuçlarına bakılmış ve 3 davranışsal önyargı ölçeği sorularının 4 faktör altında toplandiğ 1 görülmüştür. Faktör analizinde öz değer istatistiği 1' den büyük olanlar anlamlı kabul edilmektedir. Tablo 7' ye göre söz konusu 4 faktör toplam varyansın yaklaşık \%55,815'ini açıklamaktadır. Faktör analizi sonucunda elde edilen toplam varyans değeri ne kadar yüksek ise ölçeğin faktör yapısının o kadar yüksek olacağı belirtilmektedir (Tavşancıl, 2010). Bu oranın sosyal bilimlerde $\% 40$ ve üzerinde olması yeterli kabul edilmektedir (Tavşancıl, 2010).

Tablo 7. Toplam Açıklanan Varyans Tablosu

\begin{tabular}{cccc}
\hline Faktör & $\begin{array}{c}\text { Özdeğer } \\
\text { İstatistiği }\end{array}$ & $\begin{array}{c}\text { Açıklanan } \\
\text { Varyans } \\
(\boldsymbol{\%})\end{array}$ & $\begin{array}{c}\text { Kümülatif } \\
\text { Açıklanan } \\
\text { Varyans(\%) }\end{array}$ \\
\hline 1 & 5,862 & 30,853 & 30,853 \\
2 & 1,901 & 10,004 & 40,857 \\
3 & 1,521 & 8,004 & 48,861 \\
4 & 1,321 & 6,954 & 55,815 \\
\hline
\end{tabular}

$\mathrm{Bu}$ faktörler; içerdikleri madde sayısı hangi davranışsal önyargı çeşidi ile daha fazla ilgili ise ona göre isimlendirilmişlerdir. Buna göre, 1. Faktör "İyimserlik ve Kontrol Yanılsamas1" (C1, C4, C5, B5, B2, B1), 2. Faktör "Kendine Aşırı Güven" (A1, A2, A4, A5), 3. Faktör "Kontrol Yan1lsamas1" (B3, B4, B6), 4. Faktör ise "İyimserlik" (C2, C6, C3, C7) davranışsal önyargısını ölçmektedir. İyimserlik önyargısının kontrol yanılsamasıyla yakından ilişkili olduğu daha önce ifade edilmişti (Weinsten, 1980). Bu ilişki 1. faktörün oluşumunda kendini göstermiştir.

A3 nolu ifadenin, kendine aşırı güven ölçeği içerisinde yer almasına rağmen farklı bir olguyu ölçmesinden dolayı tek başına bir faktör oluşturduğu görülmüştür. Faktör ağırlığı ise 0,395 'tir. $\mathrm{Bu}$ nedenle bu soru ölçekten çıkartılmıştır. Aynı şekilde A6 nolu ifade de birden fazla faktör altında yer aldığından ölçekten çıkarılmıştır. Faktör analizi sonucunda oluşan faktörler aşağıdaki gibidir.

\section{Faktör 1 (İyimserlik ve Kontrol Yanılsaması)}

C1: Sonucu belirsiz bir durumla karşılaştığımda genelde en iyisinin olmasını beklerim.

C5: Sürekli olarak bir şeylerle meşgul olmak benim için önemlidir.

C4: Arkadaşlarımla vakit geçirerek çok eğlenirim.

B1: Her zaman verdiğim kararların oldukça isabetli olduğunu düşünürüm.

B2: Verdiğim kararların sonuçlarını tam olarak kestirebilirim.

B5: Genel olarak verdiğim kararların doğruluğu konusunda kendimden eminimdir. 
Faktör 2 (Kendine Așırı Güven)

A4: Yatırım yapma ve yönetme konusunda kendi yeteneklerime güvenirim

A1: Kendi yeteneklerime güvendiğim için fazla risk alırım

A5: Çevreme yatırım tavsiyelerinde bulunurum ve bundan asla çekinmem

A2: Verdiğim kararın doğruluğundan asla şüphe duymam

\section{Faktör 3 (Kontrol Yanılsaması)}

B4: Bir karar verilmesi gereken durumda benim vereceğim karar her zaman en doğru karardır.

B6: Kendimi bilgi birikimim açısından benimle aynı statüde olan diğer insanların üzerinde görüyorum.

B3: Aldığım bir kararın sonucunu tam olarak tahmin edebilirim.

\section{Faktör 4 (İvimserlik)}

C6: Çok kolay üzülen biri değilimdir

C2: Rahatlamak için çok çaba sarf etmem

C3: Geleceğimle ilgili olarak genellikle iyimserimdir.

C7: Genel olarak başıma iyi şeylerin geleceği yönündeki beklentim kötü şeylerin geleceği beklentisinden daha fazladir.

\subsection{Güvenirlik Analizi}

Ölçeğin genelinin ve her bir davranışsal önyargı ölçeğinin güvenirlik analizi sonuçları aşağıdaki Tablo 8 'de verilmiştir. Buna göre faktör analizi sonucunda çıkartılmasına karar verilen sorular çıkartıldıktan sonra önyargı sorularının Cronbach Alfa değeri 0,825 olarak hesaplanmıştır. Bununla birlikte kendine aşırı güven ölçeği 0,758, iyimserlik ve kontrol yanılsamas1 0,834, kontrol yanılsaması 0,628 ve iyimserlik 0,681 olarak ölçülmüştür.

Tablo 8. Güvenirlik Analizi Sonuçları

\begin{tabular}{|c|c|c|}
\hline & \multicolumn{2}{|c|}{ Faktör Analizinden Sonra } \\
\hline & Cronbach Alfa & Madde Sayısı \\
\hline $\begin{array}{c}\text { Davranışsal } \\
\text { Önyarg } \text { Ölçeği }\end{array}$ & 0,825 & 17 \\
\hline $\begin{array}{l}\text { Kendine Aşırı } \\
\text { Güven } \\
\text { İyimserlik ve }\end{array}$ & 0,758 & 4 \\
\hline Kontrol & 0,834 & 6 \\
\hline Yanılsaması & & \\
\hline $\begin{array}{c}\text { Kontrol } \\
\text { Yanılsaması }\end{array}$ & 0,628 & 3 \\
\hline İyimserlik & 0,681 & 4 \\
\hline
\end{tabular}

\section{Sonuç ve Değerlendirme}

$\mathrm{Bu}$ çalışma kapsamında, literatürde yer alan ve yatırımcı ve yönetici davranışsal önyargılarının alınan kararlar üzerindeki etkisinin incelenmesini konu alan çalışmalardan hareketle söz konusu çalışmalarda oldukça sık yer verilen üç farklı davranışsal önyargı çeşidinin ölçülmesi konusu ele alınmıştır. Bu amaçla oluşturulan ölçeğin ölçme gücü tespit edilmeye çalışılmıştır. Çalışmada öncelikle konuyla ilgili literatürde yer alan çalışmalardan hareketle hazırlanmış anket formu 81 öğrenciye iki kere uygulanmış verilen cevaplar arasındaki tutarlılık ölçülmüştür. Tutarlılığın yeterli düzeyde olduğunun görülmesinden sonra farkl üniversitelerdeki 522 öğrenciye uygulanmıştır. Toplanan veriler üzerinden yapı geçerliliği araştırılmıș ve güvenilirlik analizi gerçekleștirilmiștir. Yapılan analizler sonucunda, üç farklı davranışsal önyargıyı ölçmesi amacıyla oluşturulan 19 maddeli anket formu dört faktörlü ve 17 maddeden oluşan son haline dönüşmüştür.

Faktör analizi sonucunda ortaya çıkan bir diğer önemli husus kontrol yanılsaması, kendine aşırı güven ve iyimserlik davranışsal önyargılarının birbirleriyle olan ilişkisi ile ilgilidir. Birçok çalışmada (Weinstein, 1980; Heaton, 2002; Graham, Harvey ve Puri, 2007) söz konusu davranışsal önyargıların aynı olguyu ölçtükleri gerekçesiyle birbirleri yerine kullanılabildikleri görülmüştür. Buna karşın bu çalışmada sadece iyimserlik ve kontrol yanılsaması bu türden bir ilişkiye işaret etmektedir. Nitekim kontrol yanılsaması ve iyimserlik maddelerinden bir k1smı, birlikte, tek bir faktör altında toplanmışlardır (1. Faktör).

$\mathrm{Bu}$ çalışma sonucunda davranışsal finans alanında yapılacak ve bireylerin finansal karar alma süreçleri üzerinde kendine aşırı güven, kontrol yanılsaması ve iyimserlik davranışsal önyargılarının etkisini konu alan çalışmalarda yararlanılabilecek bir davranışsal önyargı ölçeği ortaya konulmaya çalışılmıştır. $\mathrm{Bu}$ ölçeğin güvenilirlik katsayısı ise 0,825 olarak hesaplanmıştır. Bununla birlikte gelecek çalışmalarda söz konusu ölçeğin, farklı örneklemler üzerinden, farklı ifade kalıpları ve farklı davranışsal önyargıların eklenmesi suretiyle daha da geliştirilmesi tavsiye edilmektedir. $\mathrm{Bu}$ amaçla yöntem olarak yapısal eşitlik modellemesi ile doğrulayıcı faktör analizi kullanılabilir. Ayrıca sonraki çalışmalarda, bu çalışma ortayta konan ölçek kullanılarak, yatırımcıların farklı yatırım kararları üzerindeki söz konusu davranışsal önyargıların etkisi incelenebilir. Bir sonraki aşamada ise söz konusu etkinin olumlu veya olumsuz yönleri ve olumsuz etkilerden sakınabilmek için önyargıların etkisini eliminize etme yolları araştırılabilir. $\mathrm{Bu}$ tür araştırmaların sayısının artması ile geleneksel ve modern finansın rasyonel birey varsayımı yumuşatılarak yatırım ve yatırımcı davranışlarını dikkate alan daha gerçekçi modeller ortaya konulabilir.

\section{Kaynakça}

Baker, M., \& Wurgler, J. (2004). A catering theory of dividends. The Journal of Finance, 59(3), 11251165 .

Baker, M., \& Wurgler, J. (2006). Investor sentiment and the cross-section of stock returns. The Journal of Finance, 61(4), 1645-1680.

Baker, M., \& Wurgler, J. (2011). Behavioral corporate finance: An updated survey (No. w17333). National Bureau of Economic Research. (Erişim:10.03.2018), http://www.nber.org/papers/w17333.pdf

Barberis, N. \& Huang, M. (2001). Mental accounting, loss aversion, and individual stock returns. The Journal of Finance, 56(4), 1247-1292.

Barberis, N., \& Huang, M. (2006). The loss aversion/narrow framing approach to the equity premium puzzle (No. w12378). National Bureau of Economic Research. (Erişim:10.04.2018), https://www.nber.org/papers/w12378 
Benartzi, S., \& Thaler, R. H. (1993). Myopic loss aversion and the equity premium puzzle (No. w4369). National Bureau of Economic Research. (Erişim:21.04.2018), http://www.nber.org/papers/w4369.pdf

Benos, A. V. (1998). Aggressiveness and survival of overconfident traders. Journal of Financial Markets, 1(3), 353-383.

Bouwman, C. H. (2009). Managerial optimism and the market's reaction to dividend changes. Case Western Reserve University Working Paper. (Erişim: 15.03.2018) http://web.mit.edu/cbouwman/www/downloads/Bou wmanOptimismAndDivChanges.pdf

Caballé, J., \& Sákovics, J. (2003). Speculating against an overconfident market. Journal of Financial Markets, 6(2), 199-225.

Campbell, T. C., Gallmeyer, M., Johnson, S. A., Rutherford, J., \& Stanley, B. W. (2011). CEO optimism and forced turnover. Journal of Financial Economics, 101: 695-712.

Campbell, W. K., Goodie, A. S., \& Foster, J. D. (2004). Narcissism, confidence, and risk attitude. Journal of Behavioral Decision Making, 17(4), 297-311.

Charness, G., \& Gneezy, U. (2010). Portfolio choice and risk attitudes: An experiment. Economic Inquiry, 48(1), 133-146.

Chitra, K. \& Jayashree, T., (2014), Does Demographic Profile Create a Difference in the Investor Behavior? The International Journal of Business \& Management 2 (7)

Conger, R. F. \& Wolstein, Ch. R., (2004), Managing overconfidence in pricing. Emphasis, (2), 10-13.

Daniel, K., Hirshleifer, D., Subrahmanyam, A. (1998). A theory of overconfidence, self-attribution, and security market under and over reaction. J. Finance, (53), 1839-1885.

De Bondt, W. F. \& Thaler, R. (1985). Does the stock market overreact? The Journal of finance, 40(3), 793-805.

Eisenbach, T. M., \& Schmalz, M. C. (2015). Anxiety, overconfidence, and excessive risk taking. FRB of New York Staff Report, (711).

Field, A. (2000). Discovering Statistics using SPSS for Windows. London:Thousand Oaks, New Delhi: Sage publications

Gervais, S., Heaton, J. B. \& Odean, T. (2002). The positive role of overconfidence and optimism in investment policy. (Erişim: 18.04.2018), http://citeseerx.ist.psu.edu/viewdoc/download?doi=1 0.1.1.201.474\&rep=rep $1 \&$ type $=$ pdf

Glaser, M. \& Weber, M. (2007). Overconfidence and trading volume. The Geneva Risk and Insurance Review, 32(1), 1-36.

Graham, J. R., Harvey, C. R. \& Puri, M. (2007). Managerial attitudes and corporate actions.
(Erişim:

23.05.2018),

https://weatherhead.case.edu/departments/bankingand-finance/Documents/Puripaper.pdf

Heaton, J. B. (2002). Managerial optimism and corporate finance. Financial management, 31(2), 33-45.

Hens, T. \& Bachmann, K. (2008). Behavioural finance for private banking. Chichester, West Sussex: John Wiley \& Sons Ltd.

Huang, J., Padmanabhan, K. \& Collins, O. M. (2011). The sampling theorem with constant amplitude variable width pulses. Circuits and Systems I: Regular Papers, IEEE Transactions on, 58(6), 1178-1190.

Kahneman, D., \& Tversky, A. (1979). Prospect theory: An analysis of decision under risk. Econometrica: Journal of the Econometric Society, 263-291.

Kalaycı, Ş . (2005). Spss Uygulamalı Çok Değişkenli Istatistik Teknikleri, Ankara: Asil Yayınevi

Menkhoff, L., Schmidt, U., \& Brozynski, T. (2006). The impact of experience on risk taking, overconfidence, and herding of fund managers: Complementary survey evidence. European Economic Review, 50(7), 1753-1766.

Metilda, J. M. (2015). Role of Illusion of Control Bias in Herding Behaviour. Adarsh Journal of Management Research, 8(1), 1-8.

Michailova, J. (2010). Overconfidence and bubbles in experimental asset markets. (Erişim: 05.04.2018), https://mpra.ub.unimuenchen.de/30579/1/MPRA_paper_30579.pdf

Montier, J. (2007), Behavioural Investing: A Practitioner's Guide to Applying Behavioural Finance, John Wiley $\&$ Sons Ltd. Published

Nosić, A., \& Weber, M. (2010). How riskily do I invest? The role of risk attitudes, risk perceptions, and overconfidence. Decision Analysis, 7(3), 282-301.

Odean, T., (1998). Volume, volatility, price and profit when all traders are above average. J. Finance, (53), 1887-1934.

Oskamp, S. (1965). Overconfidence in case-study judgments. Journal of consulting psychology, 29(3), 261.

Polat, Y. \& Kayaalp, G. T., (2012), Hayvanc1lik Denemesinde Faktör Analizi Yöntemlerinin Karşılaştırmalı Olarak İncelenmesi, Ç. U. Fen ve Mühendislik Bilimleri Dergisi, 28 (5), 39-48.

Pompian, M. (2012). Behavioural Finance and Investor Types: Managing Behaviour to Make Better Investment Decisions. New York: John Wiley \& Sons.

Riaz, T. \& Iqbal, H., (2015) Impact of Overconfidence, Illusion of control, Self Control and Optimism Bias on Investors Decision Making; Evidence from Developing Markets Research, Journal of Finance and Accounting 6(11).

Scheier, M. F., Carver, C. S., \& Bridges, M. W. (1994). Distinguishing optimism from neuroticism (and trait 
anxiety, self-mastery, and self-esteem): a reevaluation of the Life Orientation Test. Journal of personality and social psychology, 67(6), 1063.

Scheinkman, J. A. \& Xiong, W. (2003). Overconfidence and speculative bubbles. Journal of political Economy, 111(6), 1183-1220.

Schmidt, U., \& Traub, S. (2002). An experimental test of loss aversion. Journal of Risk and Uncertainty, 25(3), 233-249.

Schwenk, C.R. (1984). Cognitive simplification processes in strategic decision-making. Strategic Management Journal 5, 111-128.

Sharma, M., \& Vasakarla, V. (2013). An empirical study of gender differences in risk aversion and over confidence in investment decision making. International Journal of Application or Innovation in Engineering \& Management, 2(7), 497-504.

Shefrin, H. \& Statman, M. (2000). Behavioral portfolio theory. Journal of financial and quantitative analysis, 35(02), 127-151.

Shiller, R. J. (2000), Irrational Exuberance, Princeton, N.J.: Princeton Univ. Press.

Svenson, O. (1981). Are we all less risky and more skillful than our fellow drivers? Acta Psychologica, 47(2), $143-148$
Tavşancıl, E. (2010). Tutumların ölçülmesi ve SPSS ile veri analizi. Ankara: Nobel Yayın Dağıtım

Taylor, S. E. ve Brown, J. D. (1988). Illusion and wellbeing: a social psychological perspective on mental health. Psychological bulletin, 103(2), 193.

Tekin, B. (2019), Kendine Aşırı Güven ve Ölçme Yöntemleri: Davranışsal Finans Kapsamında Bir Literatür İncelemesi. Anemon Muş Alparslan Üniversitesi Sosyal Bilimler Dergisi, 7(2), 293-308.

Tekin, B. (2016). Beklenen Fayda ve Beklenti Teorileri Baglaminda Geleneksel Finans-Davranissal Finans Ayrimi, Journal of Accounting, Finance and Auditing Studies, 2(4), 75.

Trinugroho, I. ve Sembel, R. (2011). Overconfidence and Excessive Trading Behavior: An Experimental Study. International Journal of Business and Management, 6(7), 147.

Tversky, A., \& Kahneman, D. (1991). Loss aversion in riskless choice: A reference-dependent model. The quarterly journal of economics, 1039-1061.

Weinstein, N. D. (1980). Unrealistic optimism about future life events. Journal of personality and social psychology, 39(5), 806. 